\title{
INTEGRATED ARCHAEO-GEOPHYSICAL SURVEY ON VOLCANIC TERRAIN: THE CASE OF KARMIR SAR ON MOUNT ARAGATS (REPUBLIC OF ARMENIA)
}

\section{VOLKANIK ARAZI ÜZERINDE BÜTÜNLEŞIK ARKEOJEOFIZIKSEL ARAŞTIRMA: ALAGÖZ DAĞI'NDA BULUNAN KARMIR SAR TEPESININ DURUMU (ERMENISTAN CUMHURIYETI)}

\author{
Makale Bilgisi | Article Info \\ Başvuru: 27 Ocak 2018 Received: Jenuary 27, 2018 \\ Hakem Değerlendirmesi: 7 Şubat 2018 Peer Review: February 7, 2018 \\ Kabul: 30 Ekim 2018 Accepted: October 30, 2018 \\ DOI Numarası: 10.22520/tubaar.2018.os.01.011 DOI Number: 10.22520/tubaar.2018.os.01.011 \\ Harald von der OSTEN * - Pavol HNILA ** \\ Alessandra GILIBERT ${ }^{* \star *}$ - Arsen BOBOKHYAN ${ }^{\star \star \star *}$
}

Keywords: South Caucasus, Bronze Age, High-Altitude Archaeology, Geomagnetic Prospection, GroundPenetrating Radar, Photogrammetry

Anahtar Kelimeler: Güney Kafkaslar, Bronz Çağı, Yükssek İrtifa Arkeolojisi, Jeomanyetik Araştırma, Jeoradar, Fotogrametri

\begin{abstract}
This paper addresses the challenges posed by geophysical prospection in a high-altitude volcanic landscape. The case study is the site Karmir Sar, on Mount Aragats, Armenia. A major aim of the ongoing archaeological explorations at Karmir Sar is to detect, map and interpret prehistoric features on site, including the extraordinary concentration of megalithic monuments known as vishaps (“dragon stones"). This paper illustrates a workflow that has allowed us to detect archaeologically relevant features by combining geomagnetic prospection, groundpenetrating radar prospection and orthophotographs generated from image-based modelling of aerial pictures. The collected archaeological information was cross-checked through excavation and the results led to a new understanding of the site and its contexts.
\end{abstract}

\footnotetext{
* Dr., Regierungspräsidium Stuttgart, Landesamt für Denkmalpflege, Arbeitsstelle Ludwigsburg, Frauenried 3, 7 Ludwigsburg, Germany, E-mail: hvdosten@gmail.com

** Dr., Freie Universität Berlin, Fachbereich Geschichts- und Kulturwissenschaften, Institut für Altorientalistik, Fabeckstraße 23-25, 14195 Berlin, Germany, E-mail: pavol.hnila@fu-berlin.de

${ }^{* * *}$ Dr., Ca' Foscari University Venice, Dipartimento di Studi Umanistici, Dorsoduro 3484/D, 30123 Venice, Italy,

E-mail: alessandra.gilibert@unive.it

${ }^{* * * *}$ Dr., Institute of Archaeology and Ethnography, Armenian Academy of Sciences, Charentsi 15, 0025 Yerevan, Republic of Armenia E-mail: arsenbobokhyan@yahoo.com
} 


\section{ÖZET}

Bu makale, yüksek rakımlı volkanik bir arazide yapılan jeofiziksel araştırmalarla ilgili zorlukları ele almaktadır. Bu çalışma örnĕ̆i, Ermenistan'ın Alagöz Dă̆ı’nda bulunan Karmir Sar tepesi üzerinedir. Karmir Sar'da sürdürülen arkeolojik keşiflerin esas amacı, olağandışı miktarlardaki, vişap ("ejderha taşı”) olarak bilinen megalitik yapılar da dâhil olmak üzere, arazi üzerinde bulunan tarih öncesi unsurları tespit etmek, bunların haritasını çıkarmak ve yorumlamaktır. Bu makale, arkeolojik unsurları tespit etmemize olanak sağlamışjeomanyetik araştırmalar, jeoradar araştırmaları ve hava fotoğraflarının resim tabanlı modellemeleri ile oluşturulan ortofotoların birleşiminden meydana gelen çalışma biçimini ortaya koyar. Toplanan arkeolojik bilgiler, arazide yapılan kazılarla çapraz kontrole tabi tutulmuştur ve alınan sonuçlar, arazi ve içeriği hakkında yepyeni bir anlayış kazanılmasına vesile olmuştur. 


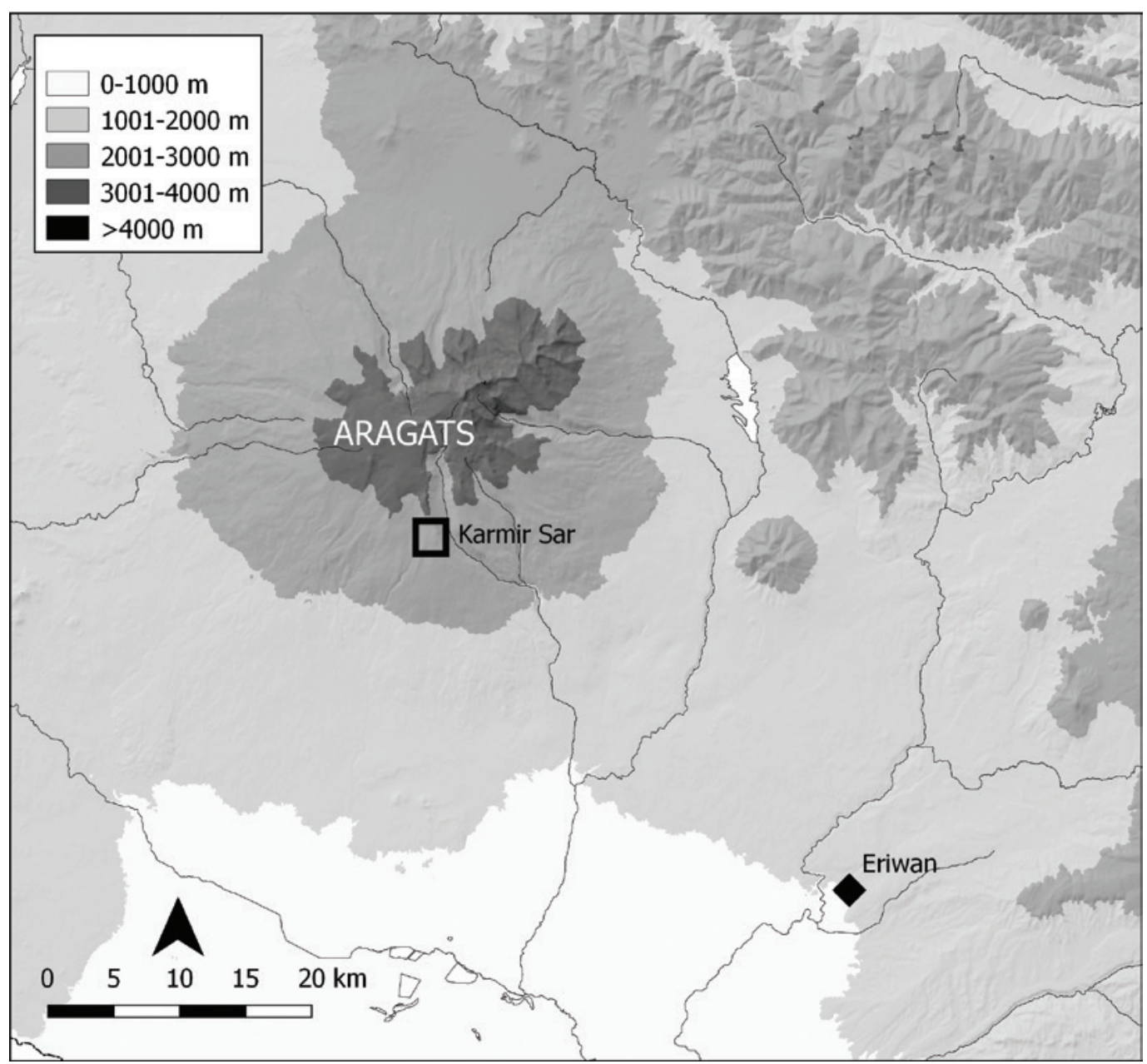

Figure 1: Map of the Surveyed Area on Aragats. (Map by P. Hnila, Topographic Data from Aster DEM and from Acopian Center for Environment) / Alagöz Dă̆ı'nda Araştırılan Bölgenin Haritası. (Haritayı Hazırlayan: P. Hnila; Topografik Verilerin Kaynaklarl Aster DEM ve Acopian Center for Environment)

This paper gives an overview of the ongoing archaeogeophysical prospection of Karmir Sar, a site located at $2850 \mathrm{~m}$ asl on the south slope of Mount Aragats. At Karmir Sar, field conditions are characterised by volcanic terrain and difficult accessibility. As we shall illustrate, we found that the local challenges posed by geology and logistics to archaeo-geophysical investigations are best met by the combination of three sensing techniques: magnetic gradiometry, photogrammetric survey with an unmanned aerial vehicle, and ground-penetrating radar.

Mount Aragats (4090 m) is a large, isolated, quaternary stratovolcano situated $40 \mathrm{~km}$ northwest of the Armenian capital Yerevan (Fig. 1). The cone has a base diameter of $45 \mathrm{~km}$, dozens of flank vents and numerous periphery plateaus. Today, Mt Aragats is considered to be an extinct volcano, since its last registered activity dates back to 0.5 million years $\mathrm{BP}^{1}$. The site of Karmir Sar (Fig. 2) is a 40-hectare, high-altitude plateau formed by Pleistocene glacial actions. Two well-watered natural springs on the northern edge of the site create an ideal summer camp

1 Connor/Connor/Meliksetian/Savov 2012 for transhumant herders. Archaeological data collected from excavated contexts indicate that Karmir Sar was visited and used for campsite activities at least from the late fifth/early fourth to the mid-second millennium $\mathrm{BC}$, and then again from the 11th century $\mathrm{AD}$ to modern times. From around $2000 \mathrm{BC}$ at the latest, the site was also used for ritual and cultic activities. These activities were centred on a variety of monuments built of local basalt stone, including numerous circular stone structures commonly termed cromlechs in Armenia (e.g., Fig. 3) or "tombs of the giants", as well as at least twelve vishaps or "dragon stones" - large-scale stone stelae sculpted with animal imagery (e.g., Fig. 4). Such a concentration of high-altitude ritual installations is unique for the South Caucasus, making Karmir Sar an excellent candidate for the study of the prehistoric use of the mountain environment for symbolic purposes.

Combined data from fieldwalking and the ongoing excavations (since 2013) have shown early on that, due to the thick carpet of meadow-grass, surface finds at Karmir Sar are virtually absent. Furthermore, only parts of the significant subsurface archaeological features are 


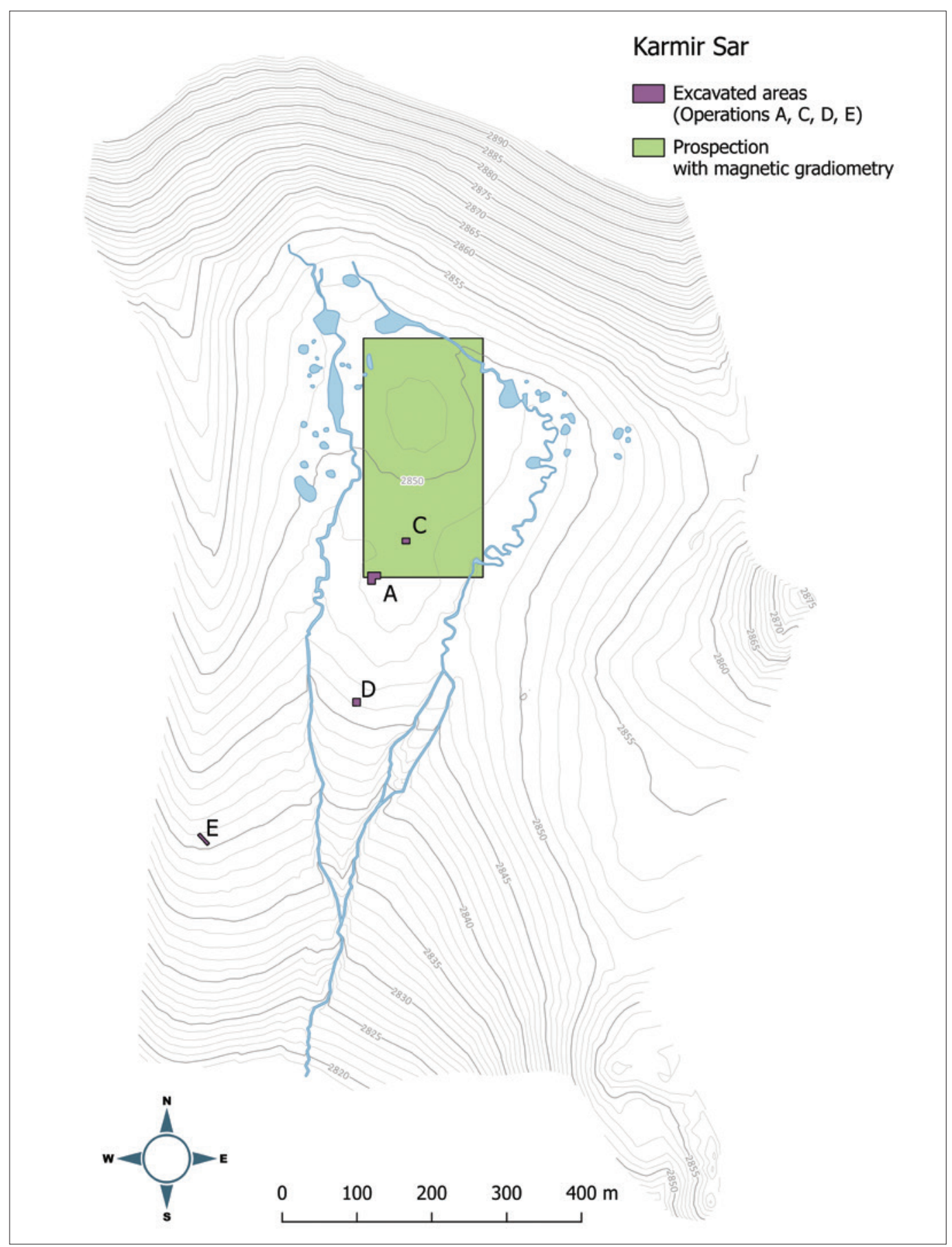

Figure 2: Plan of Karmir Sar. (Plan by P. Hnila/S. Davtyan) / Karmir Sar Tepesinin Planı. (Planı Hazırlayan: P. Hnila/S. Davtyan)

immediately detectable on the surface, although given the geomorphology, all prehistoric deposits are expected to be consistently distributed within $30-60 \mathrm{~cm}$ from the surface. Thus, important features may be invisible to the naked eye while others are faintly perceptible only from a bird's eye view. The general aim of the ongoing archaeo-geophysical survey is to help map and analyse subsurface constructions for the entire site, bypassing the limitations imposed by the field conditions. In particular, we aim to chart different types of architecture, in order to establish functional and chronological groups and study how they are distributed in space. In order to achieve our objectives, we devised a two-step integrated approach (for a comparable approach also experimented with on Mount Aragats ${ }^{2}$, for a singlemethod approach, see Herles/Fassbinder 2015).

\section{FIRST STEP: MAGNETIC GRADIOMETRY AND PHOTOGRAMMETRIC SURVEY}

Archeo-geophysical investigations began in 2014, when we prospected a surface area of $320 \times 160 \mathrm{~m}$ by magnetic gradiometry. Data were acquired using the

\footnotetext{
2 cf. Lindsay/Leon/Smith/Wiktorowicz 2014
} 




Figure 3: Karmir Sar, View of Operation A at the End of 2014 Excavation Campaign. A Fallen Vishap in the Foreground and Three Stone Cromlechs in its Vicinity. All Archaeological Features Were Found a Few Centimetres Below the Present Surface. (Photo by P. Hnila) / Karmir Sar; 2014 Yllındaki Kazının Sonunda Operasyon A Alanının Görünümü. Önde Düşmüş Bir Vişap ve Etrafinda Üç Taş Kromlek. Arkeolojik Unsurların Tümü, Mevcut Yüzeyin Birkaç Santimetre Altında Bulunmuştur. (Fotoğrafi Çeken: P. Hnila)



Figure 4: The Vishap Found in Operation C (Photo by P. Hnila) / Operasyon C'de Bulunmuş Olan Vişap (Fotoğrafi çeken: P. Hnila)

fluxgate gradiometer system Ferex 4.032, manufactured by Foerster (Reutlingen, Germany) with four dual sensors (sensor separation: $650 \mathrm{~mm}$ ) along measuring transects spaced $0.25 \mathrm{~m}$ apart. The instrument collected readings every $0.05 \mathrm{~m}$. The data from all the 32 grids (each grid is about $40 \times 40 \mathrm{~m}$ ) were assembled using Foerster's software DATA2LINE on one big grid. The binary data were finally exported to an ASCII file. The ongoing data processing consisted mainly of three steps, using the symbolic mathematical computation program Wolfram Mathematica V10.1 and so-called notebooks, which we have developed over the last few years. Using a spline algorithm, the data were fitted to a $0.05 \times 0.05$ $\mathrm{m}$ data array. Noise in the data was then suppressed using a wavelet filter and the signal to noise ratio was considerably improved. Finally, based on the histogram of the processed data, the magnetogram was created, a two-dimensional grey-levelled picture showing all the recorded geomagnetic anomalies of the surveyed area. The results showed a high number of very strong anomalies, mostly due to the presence of volcanic rocks scattered all over the prospected plot (Fig. 5). In order to separate surface anomalies caused by geology from archaeologically significant magnetic alignments, we prospected the same area by photogrammetric survey with a DIY Phantom 2 drone quadcopter, integrating the results with the data collected by autoptic observations in the field. The GoPro Hero 3+ Black Edition camera mounted on the quadcopter shot over 1000 pictures of the survey plot. The pictures were processed with the Agisoft Photoscan Professional v. 1.1.1 software in order to generate a 3D model of the terrain. The 3D model was georeferenced with the help of 45 control

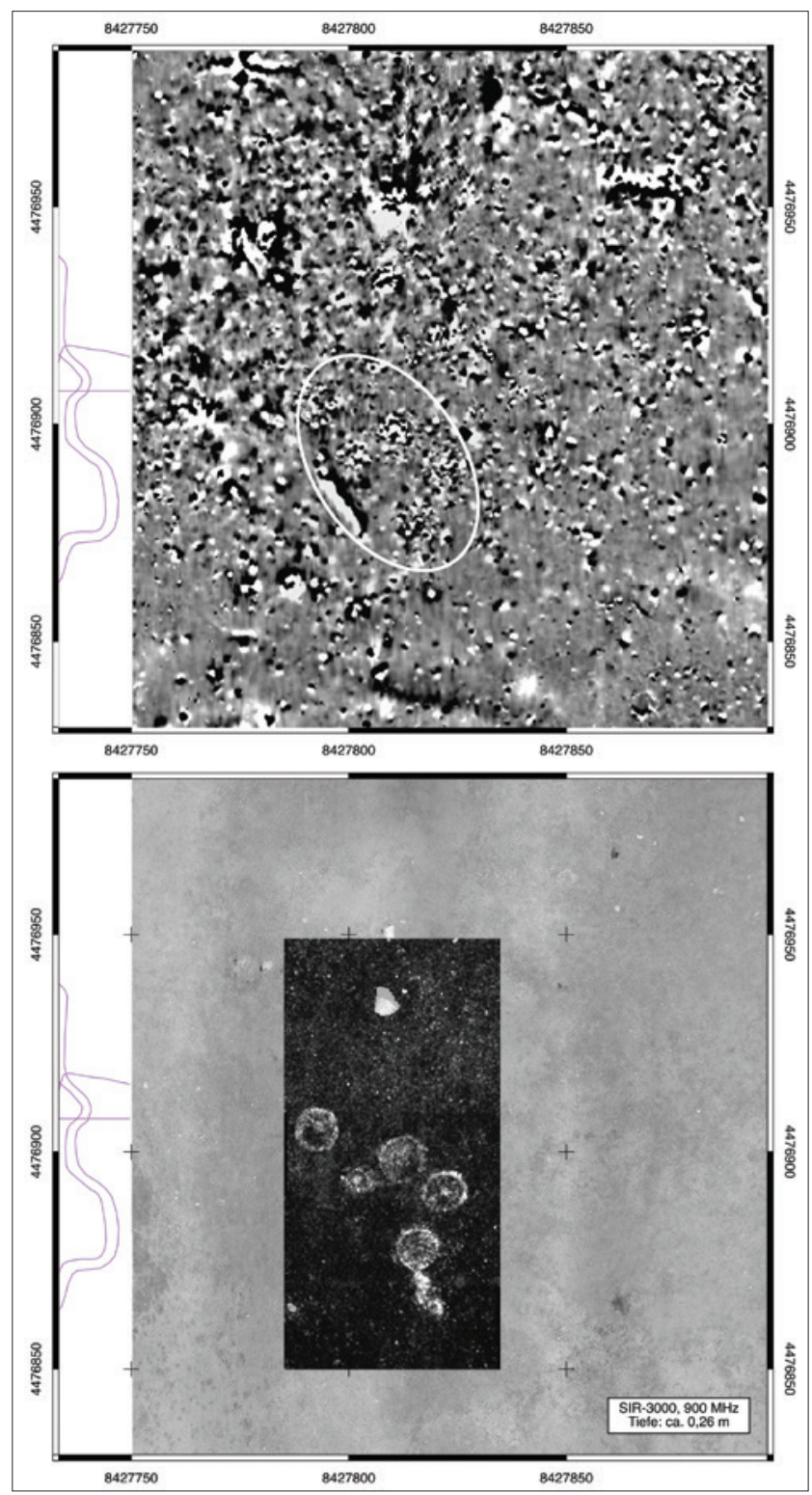

Figure 5: Five Cromlechs Prospected in Detail by GroundPenetrating Radar. Orthophoto Based on Image-Based Modelling Visible in the Background. (Plan by H. Von Der Osten) / Jeoradar Kullanılarak Detaylıca İncelenen Beş Kromlek. Ortofotolar İçin Arka Planda Görünen Resim Tabanlı Modelleme Kullanılmıştır. (Planı Hazırlayan: H. Von Der Osten) 
points distributed evenly over the surveyed area and measured by a total station. Based on the 3D model, a high-resolution orthophoto was created. On the orthophoto, a number of circular stone structures visible to the naked eye were identified and mapped. Then, we integrated the data collected by aerial survey with those of the magnetogram. In this way, we could correlate structures visible on the orthophoto with magnetic anomalies, thus creating an interpretive key to better decode the magnetogram. For example, we could see that cromlechs visible on the orthophoto overlapped with a characteristic mosaic-like pattern on the magnetogram (Fig. 5). Once we recognised this specific mosaic pattern as the magnetic signature of a cromlech, we could use the magnetogram on its own and identify subsurface cromlechs invisible on the orthophoto. In conclusion, we found that at Karmir Sar, magnetic gradiometry integrated with photogrammetric survey opened up the possibility of collecting generic data on a relatively large scale. In our opinion, this technique is an effective first step to screen extensive areas in volcanic terrain and single out the most promising anomalies to be further investigated with more detailed methods.

\section{SECOND STEP: GROUND-PENETRATING RADAR}

In 2015, archaeo-geophysical investigations switched to ground-penetrating radar, a method that, in our case, required more time per surveyed square metre but that provided incomparably more detailed results. The instrument employed was a SIR-3000 from Geophysical Survey Systems, Inc. (GSSI), USA. We knew from the excavations started in 2013 that prehistoric structures clustered at a depth of $30-40 \mathrm{~cm}$ from the modern surface. Therefore we chose to employ an antenna with a centre frequency of $900 \mathrm{MHz}$. Transects were set with a total station at a distance of $0.25 \mathrm{~m}$ or $0.125 \mathrm{~m}$ between each one, and georeferenced according to the locally used coordinate reference system Pulkovo 1942 / GaussKrueger zone 8 (EPSG: 28408). Data were collected either every $0.02 \mathrm{~m}$ or every $0.01 \mathrm{~m}$ along each transect. Signal and image processing was carried out with ReflexW 7.5, software developed by K.-J. Sandmeier' . Essentially, the data-processing flow sequence involved the following steps: time-zero correction, or correction of start time (all traces must be adjusted to a common time-zero position, where "time zero" is the place in time where the air-ground wavelet first enters the subsurface); dewow, or correction of low-frequency and DC bias data; manual gain (y), i.e., artificial correction of signal in order to counteract attenuation; band-pass filtering; low-pass filtering; and simple median filtering. We also performed a Stolt migration (also referred to as frequencywavenumber migration) on the basis of a velocity

3 Sandmeier 2015. distribution of the subsurface (i.e., the soil dielectric permittivity) with a constant value $\mathrm{v}=0.085 \mathrm{~m} / \mathrm{nsec}$. In 2015, we prospected 17 areas using this technique. In the following, three different archaeological contexts in three different parts of the site will be illustrated as an example of our results.

\section{CLUSTERS OF BRONZE AGE CROMLECHS AND THEIR INNER STRUCTURE}

The first example concerns the so-called cromlechs. Circles of stones can be observed in rather well-defined clusters in at least five distinct areas on the site's surface. One such cluster of five cromlechs was identified and excavated extensively in Operation A during the 2013 and 2014 campaigns. Originally, the area had been singled out for excavation because the upper part of a worked megalith was surfacing in a context that seemed largely free of modern disturbances. Before excavation, we observed that the surface bulged very slightly around the megalith. Similar very slight "bulges" were faintly detectable in the vicinity, but we could not connect them in any way to typologies of archaeological structures. During excavation, the chosen context turned out to be that of a vishap (see below) deposited horizontally in the centre of a cromlech. As found, the vishap was re-used in a secondary position - its original location could not be ascertained. As the excavations proceeded, a further two adjacent cromlechs were uncovered, with diameters of $3 \mathrm{~m}$ and $6 \mathrm{~m}$ respectively, and with depositional pits in their centres containing ceramic material dated between the end of the third and the beginning of the second millennium BC. In order to determine the exact extension of this cluster of cromlechs, in 2015 we prospected the area around Operation A with the ground-penetrating radar. The results indicated the existence of two further cromlechs in the immediate vicinity (Fig. 6B). One of them was subsequently excavated, bringing to light the best-preserved cromlech context found at Karmir Sar so far, including a stone chamber with decorated pottery and jewels. Both pottery decoration and a C14 sample of charcoal from the chamber point to an absolute date towards the end of the third millennium BC (the $\mathrm{C} 14$ sample was dated in Mainz as MAMS 25322, 3723 \pm 22 and it dates with $95.4 \%$ probability to between 2200 and 2036 calBC according to the calibration with IntCal13). The ground-penetrating radar also showed us that faint bulges to the west of this latter cromlech correlated to rows of stones set at a higher level along an orthogonal grid, which we interpreted as recent traces of a tent camp and so decided not to excavate.

The experience of combining excavation and groundpenetrating radar in Operation A taught us that the identification of cromlechs on the surface of Karmir 
Sar is not straightforward: not all cromlechs are visible on the surface, and not all surface "bulges" are to be interpreted as cromlechs. It seemed important to us to test the presence or absence of clusters of cromlechs through geophysical surveys. Turning to the magnetogram and interpreting it with the aid of the orthophoto, we were able to roughly identify five circular structures c. 120 $\mathrm{m}$ north of Operation A, only three of which had been partially visible with the naked eye. This seemed to be a cluster of cromlechs cognate to that excavated in Operation A. Therefore, we defined a square area of $100 \times 50 \mathrm{~m}$ comprising all identified structures and conducted an investigation with ground-penetrating radar. This investigation led to additional detailed results concerning both the extension and the inner composition of the circular structures (Fig. 5). The time-slice map at $0.26 \mathrm{~m}$ depth indicated that the diameter of the circular structures varied between $10 \mathrm{~m}$ and $12 \mathrm{~m}$. Additionally, the same time slice pointed to the existence of deeper square structures at the centre of each stone circle. These central anomalies could be traced up to a depth of 0.82

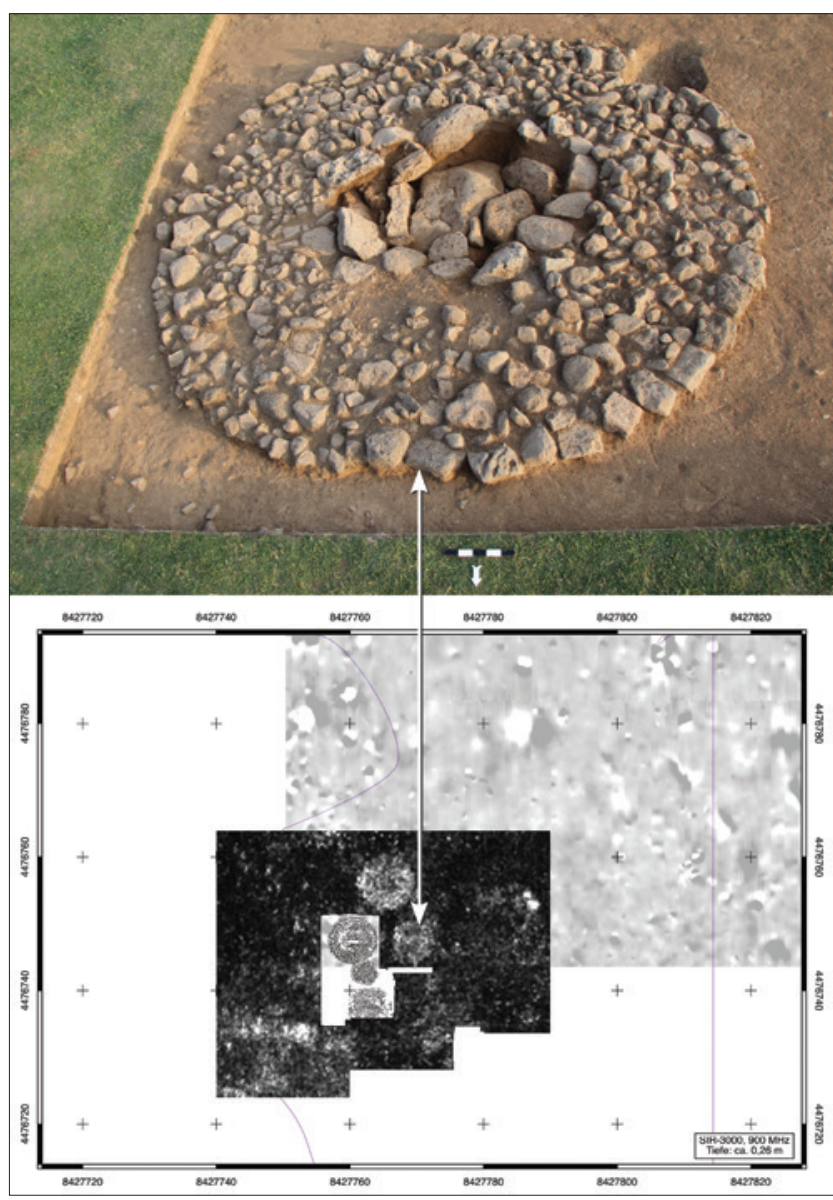

Figure 6: A) Karmir Sar 2015, View of Cromlech No. 4 in Operation A During the Excavation (P. Hnila); B) Two New Cromlechs Discovered by Ground-Penetrating Radar Near Operation A at the End Of 2014 Campaign. (Plan by H. Von Der Osten) / A) Karmir Sar, 2015; Operasyon A Alaninin Kazısı Sirasinda Elde Edilen 4 Numaralı Kromlek Taşının Görüntüsü (P. Hnila); B) 2014 Kazısının Sonunda Operasyon A'ya Yakın Bir Yerde Jeoradar Ile Keșfedilen İki Yeni Kromlek. (Planı Hazırlayan: H. Von Der Osten) $\mathrm{m}$, a depth where the outer circular structure had already disappeared completely. Parallels with the results of the excavations in Operation A support an interpretation of these inner square structures as stone (burial?) chambers built for the deposition of offerings or grave goods. We identified a cluster of cromlechs apparently analogous to that in Operation A, but with two differences that may be significant: the identified structures are larger than those in Operation A, and none of them has a vishap or a comparable megalith embedded in its centre (as opposed to those in Operation A).

\section{THE VISHAPS}

By walking the site systematically, we were able to identify 12 decorated megalithic stelae on the surface, so-called vishaps or "dragon stones" (Fig. 2). All of them were recorded in fallen positions, some of them fragmentary or evidently displaced. At least five vishaps were sunk rather deeply into the ground, suggesting a final deposition a long time ago. Operation A was started around one such vishap, which turned out to have been used as an architectural part of a cromlech (Fig. 3, see description above). The excavations could not clarify whether the cromlech was to be considered the primary context of the vishap, or whether the vishap had been re-used within the cromlech but originally conceived for another context of use. If the vishap and cromlech at Operation A were conceived together from the start, we may expect vishaps in general to go hand-inhand with cromlechs, a pattern that we had already observed during our survey in the Geghama Mountains ${ }^{4}$. To test this hypothesis, we prospected two further unexcavated vishaps using ground-penetrating radar, in areas labelled "Operation C" and "Operation D" (Fig. 2). The results show that the two prospected vishaps are not embedded in cromlechs, nor are cromlechs to be detected in their immediate vicinity, although loose groups of small-to-medium-sized stones were detected. Both contexts were subsequently excavated and in both cases we recorded traces of modern small-scale illicit digging. In Operation C, the radar detected the diffuse presence of small stones at a depth of $0.11 \mathrm{~m}$ (Fig. 7). They turned out to be a Pleistocene gravel heap resulting from a pit dug next to and partially beneath the vishap: the pit had cut into the geological layers, hence the gravel in the spoil. The context was in general heavily disturbed (Fig. 8). We recorded the presence of a working area next to the vishap, with a considerable amount of fragments of rough, handmade pottery as well as traces of an ad-hoc production of obsidian tools. Investigation is still open to determine the exact temporal and functional relationship of this activity area to the vishap. Excavations in Operation D uncovered a comparable context with fewer modern disturbances and fewer traces of domestic activity. The vishap in Operation D was found collapsed (more accurately, it had been made to

${ }_{4}$ Gilibert/Bobokhyan/Hnila 2012 
collapse) in front of its original foundation pit. By falling, the megalith had partially disturbed the foundation pit, spreading around some of the stones used to keep the vishap standing. In the vicinity we also recorded at least two stone instruments used to pick and polish the relief on the vishap. By falling, the vishap had sealed a platform consisting of stone slabs and a hardened surface (for offerings?). The platform was originally built in front of the worked face of

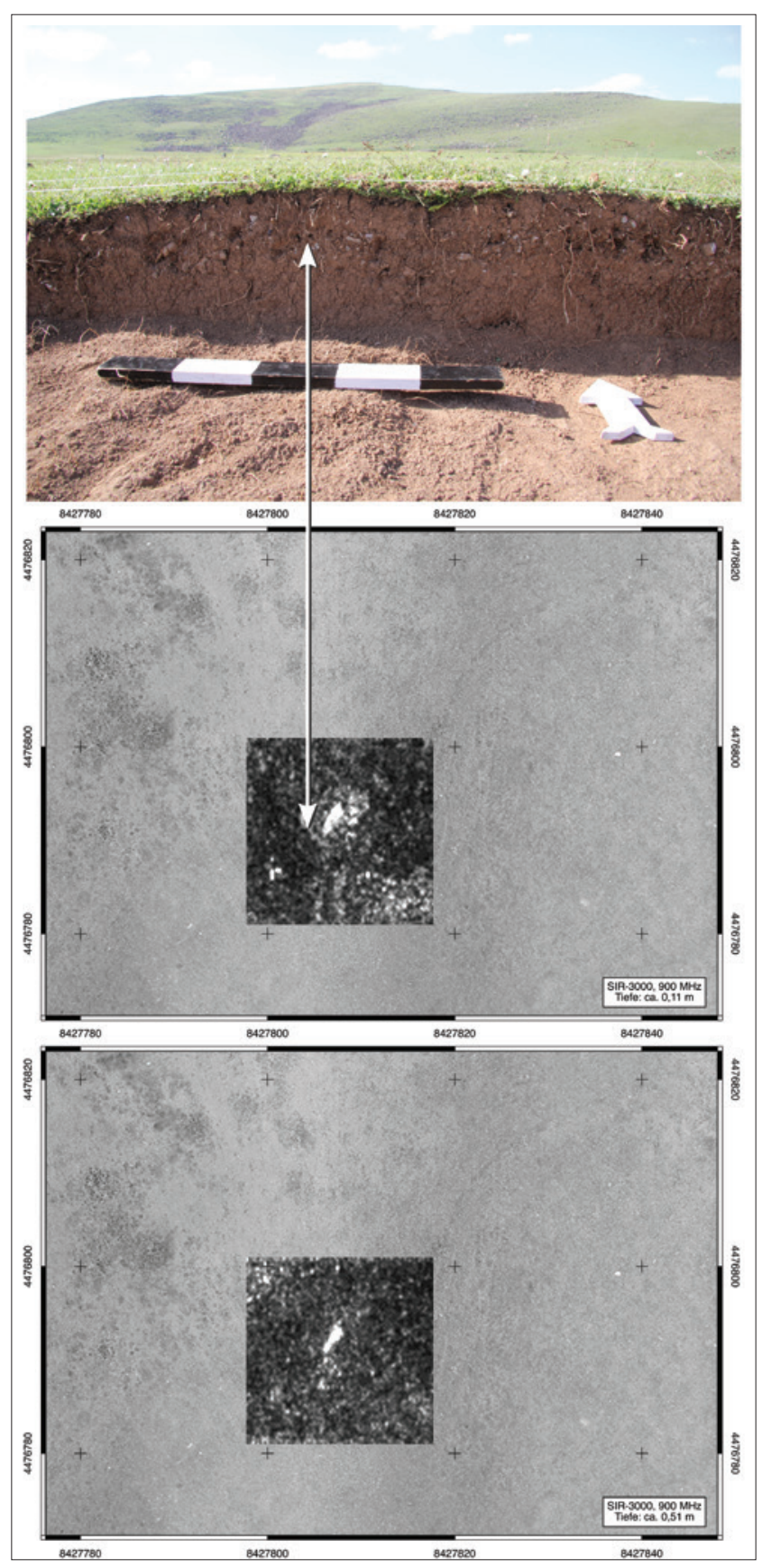

Figure 7: Visualisation of the Selected Time Slices of GroundPenetrating Radar Prospection Near the Vishap in Operation C. The Weak Circular Anomaly is Based on Gravel Pieces $\leq 1$ cm. (Photo by P. Hnila, Plan by H. Von Der Osten) / Operasyon C'deki Vişap'a Yakın Bir Konumdaki Jeoradar Incelemesinden Seçilen Zaman Dilimlerinin Görselleştirilmiş Şekilleri. Zaylf Sirküler Anomali, 1 Santimetre Veya Daha Küçük Boyuttaki Çakıl Parçaları Üzerine Kuruludur. (Fotoğrafi Çeken: P. Hnila; Planı Hazırlayan: H. Von Der Osten) the vishap. This is the first indication of the original context of vishaps, which now appear to have been conceived as solitary standing monuments with ritual installations in front of them. A number of medium-sized stones recorded around the fallen vishap are provisionally interpreted as later additions to the context. The materials collected around the vishaps and among the surrounding stones include Middle Bronze Age pottery as well as a small collection of obsidian tools typical for the end of the fifth-end of the second millennium BC (Purschwitz, forthcoming). C14 analysis of coal samples from the stone structure sealed by the fallen vishap is being performed at the Weizmann Institute (Israel) and may help clarify dating matters in the near future. In conclusion, concerning the contextual analysis of the vishaps, the ground-penetrating radar has proved a quick and non-invasive way to avoid false inferences about their context and optimize excavation strategies.

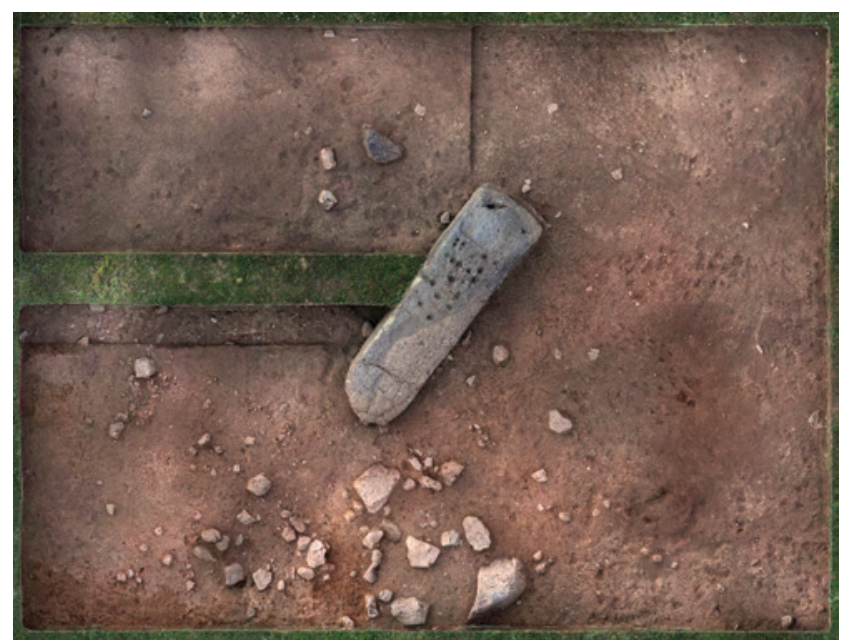

Figure 8: Operation C-Orthophoto of the Vishap and Surrounding Stray Stones During the 2015 Excavation Campaign. (Photo Generated by P. Hnila) / Operasyon C - 2015 Kazı Dönemi Sirasında, Vişap Ve Etrafında Dağınık Olarak Bulunan Taşların Ortofotosu. (Fotoğrafi Çeken: P. Hnila)

\section{AN EARLY MEDIEVAL CIRCULAR STRUCTURE}

Beyond the study of megalithic cult and funerary structures, investigations at Karmir Sar also aim to locate ancient seasonal settlements or tent encampments. At a 40-hectare site with a surface sealed by a thick grass carpet, with virtually no small finds on the surface, the task is challenging. As a first attempt in this direction, in 2016 we decided to prospect an elevated area located $415 \mathrm{~m}$ south-west of Operation A, right on the edge of the site (Fig. 9). In this area, labelled "Operation E", the surface survey recorded the existence of an unusually extensive circular stone structure of unclear nature (diameter $14 \mathrm{~m}$ ). The stones were too loose and scattered to be yet another cromlech. Rather, we considered it more likely that the structure was connected to domestic or animal keeping activities. To test this hypothesis, we decided to employ ground-penetrating radar. The prospection with 


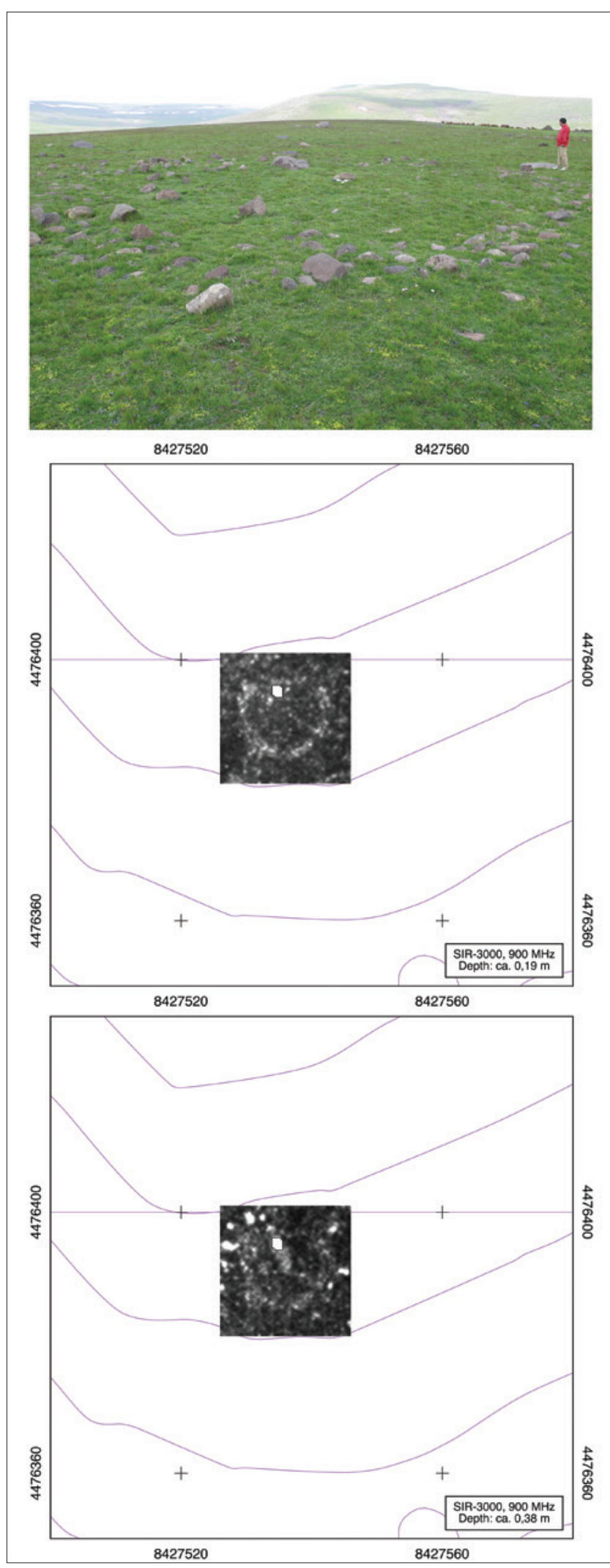

Figure 9: View of the Circular Stone Structure Interpreted as a Medieval Animal Corral in Operation E Before the Excavation (Photo by P. Hnila). Prospection of the Circular Stone Structure by Ground-Penetrating Radar - the Rectangular White Area without Data Marks the Position of a Big Boulder That Could Not Be Surveyed. (Plans By H. Von Der Osten) / Kazı Öncesi, Operasyon E Alanında Bulunan, Ortaçağ Hayvan Ağılı Olarak Yorumlanmış Dairesel Taş Yapının Görüntüsü (Fotoğrafi Çeken: P. Hnila). Dairesel Taş Yapının, Jeoradar. the ground-penetrating radar was conducted all over the area, except for the surface occupied by a large boulder, slightly off the centre of the structure, which therefore appears as a transparent surface in the time slices. The time slices show a single row of stones immediately underneath the surface, set in a circular fashion, with a total detected height of $\mathrm{c} .10 \mathrm{~cm}$, between 0.28 and $0.38 \mathrm{~m}$ deep. The radar detected occasional singular stones outside the circle, but virtually none inside. A test trench opened in the last days of the 2016 excavation confirmed the results of the geophysical investigations, additionally identifying an opening in the north side of the circular structure. Pottery sherds are consistent with a medieval date. A Byzantine coin, a so-called follis, was found immediately outside the structure. It was minted during the reign of Basil II and Constantine VIII (976-1028 AD - and according to Ruben Vardanyan and Hasmik Hovhannisyan, History Museum of Armenia [personal communication], its small size and low weight suggest a more precise date in the $1010 \mathrm{~s}-1020 \mathrm{~s}$ AD). Since no traces of domestic activities were detected inside the structure, we provisionally interpret the context in its entirety as a high medieval animal corral.

\section{CONCLUSIONS}

Karmir Sar is a large megalithic site characterised by volcanic terrain and low accessibility. Investigations by classic pedestrian survey are severely hampered by the thick grass carpet. Under such conditions, we found that the best strategy for a large-scale study of the site is the combination of magnetic gradiometry, photogrammetric survey, and ground-penetrating radar. Magnetic gradiometry has the benefit of covering extensive areas relatively quickly. Yet it has a downside on volcanic terrain: the results are complex, blurry and difficult to interpret because archaeological features are obscured by numerous anomalies of geological origin. We found that magnetic gradiometry is best used as the first step of a two-step approach integrating different methods. The first step of our integrated approach also includes a photogrammetric survey. The photogrammetric survey generates a high-resolution orthophoto of the surface that can be superimposed over the geomagnetic anomalies and thus render the results of the magnetic gradiometry more legible. This workflow enables us to partly decode the magnetogram - to filter out most of the geological anomalies and single out archaeologically significant areas to be targeted with a higher-resolution method. The second step, the higher-resolution part of our integrated approach, is prospection using ground-penetrating radar. Through this time-intensive method, we obtained detailed results for relatively small areas. Following this ideal two-step protocol, it is possible to obtain a geomagnetic map of a site with different levels of detail which can be set according to the research focus and not left to chance. 


\section{BIBLIOGRAPHY}

CONNOR, L.J./CONNOR, C.B./MELIKSETIAN, K./ SAVOV, I. 2012

"Probabilistic Approach to Modeling Lava Flow Inundation: a Lava Flow Hazard Assessment for a Nuclear Facility in Armenia", Journal of Applied Volcanology 1: 1-19.

GILIBERT, A./BOBOKHYAN, A./HNILA, P. 2012

"Dragon Stones in Context. The Discovery of HighAltitude Burial Grounds with Sculpted Stelae in the Armenian Mountains", Mitteilungen der Deutschen OrientGesellschaft 144: 93-132.

HERLES, M./FASSBINDER, J. W. E. 2015

"Magnetic Prospecting on Basaltic Geology: The Lower City of Erebuni (Armenia)", Archaeologia Polona 53: 292296.

LINDSAY, I./LEON, J./SMITH, A.T./WIKTOROWICZ, C. 2014

"Geophysical Survey at Late Bronze Age Fortresses: Comparing Methods in the Diverse Geological Contexts of Armenia", Antiquity 88/340: 578-595.

PURSCHWITZ, C. forthcoming:

"Chalcolithic and Middle Bronze Age Obsidian Industries at Karmir Sar: Characterization of Lithic Economies from the Armenian Highland", Journal of Lithic Studies 5.

SANDMEIER, K.-J. 2015

ReflexW, Manual Version 7.5. http://www.sandmeier-geo. de. 